\title{
Love knows no boundaries. The study of contemporary Czech-Polish family relations inspired by the documentary entitled "Para mieszana"
}

Andrzej Ładyżyński / aladyzynski@gmail.com Institut of Pedagogy, University of Wrocław, Poland

Ładyżyński, A. (2014). Love knows no boundaries. The study of contemporary Czech-Polish family relations inspired by the documentary entitled "Para mieszana." Czech-Polish Historical and Pedagogical Journal, 6/2, 21-29. doi: 10.247/cphpj-2014-0015

The article discusses Polish documentary film "Para mieszana" ("Mixed couple"). Film was released in 2005, directed by Kinga Dębska and Lenka Wimmerová. The document shows episodes of everyday life of four mixed couples living together in Czech Republic and Poland. Their life is shown on many levels: marriage, family and career. Every couple is in different stage of live, dealing with various difficulties. The article presents interpretation of family structure, language and space of their living activities as well as their world of values.

Key words: love; documentary film; family relationships; Czechs; Poles

\section{Poles and Czechs - the charm of the vicinity and the power of stereotypes}

Relations between Czech Republic and Poland are very old, taking into account the vicinity between countries. They are connected by important historic events. Alliance of Poland with Czechs was marked by the adoption of Christianity in Poland. The first significant dynastic marriage was contracted between the ruler of Poland, duke Mieszko I and the duchess of Czech, Dobrawa. Czechs and Poles had common rulers, enemies and alliances. Czech reformation had a great exert on Polish one. For the pedagogues, works of Jan Ámos Komenský of Moravia are of tremendous salience.

Not all the common historic events constitute reasons for pride and common joy. Military action of Czechs in January $1919^{1}$ affected the

1 Kamiński, M. K. (2001). Konflikt polsko-czeski 1918-1921. Warszawa: Instytut Historii PAN, Wydawnictwo Neriton, p. 9. 
relations between both countries during the interwar period and it finished with the intervention of Polish military forces in Transolza in 1938. The vision of tanks in Prague in 1968 makes Polish society ashamed, even though it had no influence on that situation. There are some glorious, but not well-known events such as participation of Czech volunteers in the September Campaign of 1939. We are accompanied by the stereotypes. ${ }^{2}$

Poles have issue with Czech culture and with southern neighbours itself. This problem could be referred to as a cultural and linguistic vicinity and simultaneous strong feeling of disparities. Quoting Dorota Siwor we can say that Czechs are: Close to us, similar in many aspects, and though at all not the same (...) it may seem that close vicinity means growing up in similar cultural conditions, but that is not so. Despite of close geographical location, we are separated by historic experience, disparate sensitivity and outlook on the world. ${ }^{3}$ On the one hand, north neighbours are amazed and proud of the Czech culture and people and on the other hand kind of specific, not understandable to the full extent, distance fraught with stereotypes. This feeling can be described as "the neigbouring syndrome". Usually living in close vicinity is the source of common joy, but this closeness can also be the seed of conflicts and teething dissensions caused by the difference of interests or disparate outlook on life. These situations happen in relations between neighbours separated by a fence as well as those separated by a boundary. Jerzy Marek being knowledgeable of Czech Republic concludes in the following way: It is the one thing that is common to us: tragic history. We have similar experiences: relatively early loss of the independence and problems with the neighbouring countries. ${ }^{4}$

Since centuries people living with each others at the brink of cultures have been curious about their neighbours. Despite of being resented by the homogenous societies, marriages between people out of their cultural area (amalgamation) were quite frequent between the people of neighbouring countries. This type of relationship is not an invention of the contemporary times. In the societies living at the boundaries of the neigbouring countries and in the cultural, religious and linguistic melting pots, marriages were not a rarity.

It is worth focusing on the most important aspects of building good relations between neighbours basing on the matters common to both

2 http://www.korzenie.info, 31. 08. 2012.

3 Siwor, D. (2013). Dlaczego o nich? In: Czuli barbarzyńcy. O kulturze czeskiej w XX wieku. Bielsko-Biała: Kolegium Nauczycielskie, p. 5.

4 Marek, J.: Dlaczego o nich? In: Czuli barbarzyńcy..., p. 17. 
nations. Looking at these relations from the perspective of Poland the most significant linking factor is culture. Czech culture is of great popularity in Poland. Books written by Franz Kafka, Bohumil Hrabal, Jaroslav Hašek are continuously popular with many readers in Poland. Karel Gott, Helena Vondráčková and Ivan Mládek are artists who gained a widespread acclaim in Poland. Jaromír Nohavica has won many Polish hearts during his concerts. Viewers from the south are deeply intrigued by the excellent Czech films. Larks on a String (Czech: Skřivánci na niti) based on the novel by Bohumil Hrabal constitute an example of the warm humour, being a specific equivalent of The man of steel (Člověk z železa), but produced with a light Czech humour. Poles are awed by the beauty of Prague or Czech thriftiness. In 1980s there existed illegal Polish-Czech Solidarność. Poles were mentally seconding Czechs during The Velvet Revolution. They were impressed by Czech politicians: Václav Havel and Václav Klaus. ${ }^{5}$

\section{Methodological approach}

Film can constitute a research matter in many scientific fields. ${ }^{6}$ Beginning its interpretation, one must precisely determine the aim of the research or state whether he is interested in the interpretation of the whole or a particular part of the film, or relations that bond the protagonists together. It is equally important to ask question or a series of questions adequately, hoping that this analysis will provide credible and convincing answers to these questions. ${ }^{7}$ Selecting from the variety of methodological approaches for the purpose of the analysis of the film, I am separating the basic information about it and subsequently I will focus on the analysis of its content, plot, pictures and dialogues hoping that the said content and its form constitutes a constructive description of the film. 8

Love in the intercultural relations implies questions about:

1. What is the structure of intercultural relations presented in the documentary?

2. What is the meaning of the language used by families in the film?

3. In what spheres are the protagonists presented?

4. Which everyday activities are presented in the film?

5 http://www.korzenie.info, 31. 08. 2012.

6 Heman, A. (1985). Przedmiot i metody filmoznawstwa. Łódź: Wydawnictwo Łódzkie, p. 13.

7 Nurczyńska, E. (1984). Filmowe analizy i interpretacje w szkole. Łódź: DKF Łódzki Dom Kultury, p. 13.

8 Nurczyńska, E. (1977). Kino i telewizja w praktyce szkolnej. In: Kino i telewizja. Warszawa: WSiP, p. 218-220. 
5. Which values implemented by the intercultural relations can be seen in the film?

6. What are the difficulties of people creating such intercultural relations? Documentary film broadcasted in Telewizja Polska is being put under the analysis. What is also significant is the fact that this unique masterpiece can be watched online. I selected the matters from the film subjectively and purposefully. Subject of my analysis are the relations between couples, taking into account cultural, linguistic and religious differences. "Para mieszana" is a 52-minutes Polish documentary film concerning Polish-Czech and Czech-Polish couples. It was produced in 2005 by Telewizja Polska in cooperation with The Polish Film Institute. Pole - Kinga Dębska and Czech - Lenka Vimmerová are film directors. The picture shows moments of everyday life in marriage, family and at work of four couples living together in Czech Republic and in Poland. Each of them is at the different phase of life. Each couple is accompanied by different feelings and the atmosphere in the relationship. The film gives an interesting insight into lives of these couples coping with cultural, linguistic and religious differences.

\section{Film protagonists}

The analyzed document presents four family relations in different contexts. Intercultural character and relations established above the boundaries and cultural disparities. Hence, the title love that knows no boundaries.

Protagonists from the first part of the film are engaged and they are preparing to enter marriage in Czech Republic. The young couple Lenka and Wojtek are very congenial. They met each other at the University. Each of them looks at the church liturgy from a different perspective. The woman is a little amused by the preparations and the nuptial ceremony, at the same time she takes it extremely emotionally. On the other hand the fiancé treats marital rite of transition very seriously. There are elements of Polish and Czech culture interwoven in the wedding ceremony. This scene makes the couple appear greatly interesting.

Alice and Mateusz are married middle-aged couple. They have two little daughters, they reached life stability and live in a big, comfortable house in a village in Poland. In the episode, family makes preparations for a outdoor fire, does shopping and talks sitting in front of the fire.

The third part is devoted to an informal relationship between Silvie and Józio. He is experienced middle-aged man who lives in cohabitation with 
13-years younger Czech. They both work in the theatre in Cieszyn. Their life is shown within the context of everyday routine, visits at the grown-up sons houses and at work.

The last part depicts Ewa and Čestmír's relationship. They live in the modest, constantly requiring repair, old house in Karkonosze. Both are experienced in love, he was in informal relationship, but woman had civil marriage. This part of the document shows the autumn of their life.

\section{Language of the characters}

Each family differently manifests discrepancies connected with cultural ethnicity. Spheres of differences concern language, religion and the attitude towards religious denomination. Language of the protagonists is worth paying attention to. When in each others' company they use both languages interchangeably. As the example can be used the engaged couple changing their marital status at the viewer's eyes. The scene, in which the couple preparing to the liturgy is learning their vows is worth mentioning. Young man and woman are using their native languages. Making their vows they articulate its text in their native languages in the sacred form and tradition. This verbalization of marital vows can be acknowledged as a form of espousal of not only these two people, but also of two similar, neighbouring, but simultaneously different cultures. A priest constitutes an interesting "uniting factor" of disparities between them. Polish priest communicates with the young couple in Polish and Czech, interchangeably. Second pair talks with each other, in Czech and English, using only Czech to communicate with daughters, although they live in Poland. The third couple uses Czech language. They are not afraid to use language, they operate the whole range of the lexicon. In the communication of the mature couple Czech prevails over Polish language. One cannot generalize that Czech language predominates Polish on the basis of these four examples.

\section{Setting of the film}

Spaces presented in the film are the result of the implementation of the directors' concepts, but they also reflect real interiors and locations, in which people live, work and rest. Young engaged couple often stay at the parish office, at church, home and its surroundings, in the outdoor photographic scenery, at the rails. Especially, the scenes set at the rails 
caught my attention. Woman in the wedding dress and man wearing black suit are photographing each other between steel rails. Rails are the symbol of the road. Two rails may be seen as the representatives of two different cultures, set at the parallel, heading into one common direction. The middle aged couple in the phase of easily noticeable stabilization, is presented in the house, in the vicinity of it, in the shop and outdoors sitting around the fire. Scenes with cohabitants of different age are located in the flat, during everyday chores, preparing the meal, at work in theatre, during meeting of men in the bar or shopping. The world of the last couple is presented around their house.

\section{Routines of the people shown in the film}

Documentary shows feelings and experiences of the young couple in the anticipation of their wedding, during activities and preparation for the wedding, rehearsal of their first dance, wedding liturgy and the wedding ceremony. The second family does the shopping and prepares the fire. The couple of cohabitants work at the house and outdoors, they are visiting sons from the man's first marriage. In the fourth pair, woman sweeps the yard, prepares meals in the kitchen, man fixes the old roof.

\section{Tough experiences in the relationships}

The engaged couple makes some preparations in the prospect of their transition to the pair of spouses. Although it doesn't seem to be a hard experience it evokes some understandable emotions in them. The exemplification of that feelings is the scene that shows bride being nervous during preparations for the wedding.

In the family with a stable status, a middle aged couple overtly shows some hardships of living in the marriage and in the community. Wife Alice was singing and dreaming about the career of a singer. She did not manage to achieve her success. She talks about it in the following way: I did not fulfill my dream. Marriage with Pole and moving out of her native country and focusing on raising children prevented her from following her career. Mateusz who is an artist and a musician either did not fully accomplish his goals. Prose of life forced him to focus entirely on securing materially his family. Nevertheless, both seem to be satisfied with their lives, but their relationship is not fully fulfilling for them. Woman expresses her longing for her homeland and family. Her words can be read as following: 
Sometimes I am thinking what it would be like if I stayed in Czech Republic. Here, I am completely withdrawn from the company of other people. I am a very sociable person. In Poland I have never worked in the company of other people, I am constantly at home with Mateusz. I am continuously thinking how my life would be different if I stayed in Czech Republic. Would our marriage last? And I would be surrounded by other men. Here I am solely with Mateusz. (...)If my life turned out differently, I would live in other country and enjoy the company of many men. There is another thread of her story: When children were born I felt terribly lonely. I hadn't have anyone to help me and Mateusz wasn't of any help either. It was a really hard time for me. (...)It wasn't a light life. The scene, in which married couple is talking by the fire is worth commenting. Woman is talking about her desolation after giving birth to her children, separation from her family, roots and social life. Her husband, Mateusz concludes on his wife's remarks: We had rough time fighting to save our marriage (about the beginning of their relationship), then children were born.

The third couple considers entering into marriage. Woman yearns for such stabilization and solution for life. She would like to have a baby. Her motivation for marriage is straightforward: I would marry you, if I were pregnant. So baby has a father. On the other hand, man after the earlier relationship does not want to enter into such relation. It is a result of the context of his life situation. He has two grown-up sons from his first relationship, who life separately but need his financial support. They do not pay rent and one of them has problems with drugs. The father has not good relations with his sons. It is a very sad picture of the couple's life. Scenes with his sons are also gloomy. The relation between two cohabitants is going through a tough moment. It is reflected in woman's utterance: You didn't kiss me goodbye. You used to kiss me goodbye every night, also on the forehead. And now nothing. You just keep on turning your back on me.

The fourth scene is centered around the problem of the inability to enter into sacramental marriage. The couple, after breaking up with their earlier partners was refused to get married in the Catholic Church. Cestmir was baptized in Czech church, which is not acknowledged by the church officials. The woman, who is catholic takes it very emotionally. She really wants to marry Cestmir. Man doesn't take it as a serious obstacle. He shows distance towards some matters. As a follower of the Hussite Church he remarks on that in the following way: We live here in a pagan den and Ewa wants to convert and turn me on the right track. On the one hand, I have to emphasize your great tolerance for the religious matters, on the contrary your little tolerance when I need to buy tar paper 
to fix the roof. There is another difficult issue. Woman talking to a teenage girl(may be granddaughter) mentions her relationship with a Black man. One of the reflections sounds in the following way: In such situations cultural differences are much bigger. It is not directly stated whether this text refers to her earlier relationship or to the present. Woman comments on that in these words: It is a different way of thinking. I don't say that it is a way of life. A friend of the house remarked in the interesting way. He point out the cultural difference: Because Catholicism, which comes from Poland isn't very familiar to me as a Czech.

\section{Values of the family life}

Life of the engaged couple demonstrates the early stages of their common life. Scenes showing the young couple is emanating with freshness. The joy of getting married is noticeable, their hope for the future can be felt.

Spouses who have two daughters ensure themselves of the longevity of their relationship and evaluate it favourably. Their positive strength can be heard in their talks. The woman says: When we got married I was sure it is for life. And I still think so. The man comments: Everything is all right and that's why we are together. I think that taking into account all our decisions in life, we were very lucky.

Ewa from the last film sequence talks about respect she has for her husband despite of his outlook on life. I never think that he is an atheistic Czech. I have absolutely never thought in those categories. Maybe I am not really Polish, am I? As we can see partners do reach compromises.

\section{Conclusions}

The documentary film depicts intercultural everyday life and discrepancies that can be found in the families. Characters in the film differ in age, social status and their life situation. Family experiences that are shown in the film can be seen from two perspectives. The first one is natural and it presents building of the relations between people-women and men, irrespective of the cultural context. The second constitutes an insight into experiences of couples in the perspective of relationships represented by people from different countries, using different languages, living in different cultures and having different denominations. Both perspectives pervade each other and they cannot be separated. 
This film shows solely four varied cases of life experiences of the contemporary people, their variety, the experiences of being entangled into difficult situations and the specificity of building a relationship. A mixture of formal relations: the engaged couple, married couple, cohabitation involving children from another marriage and an informal relationship of elderly people shows the array of contemporary families in the complexity of their situations. Even the engaged couple has to overcome cultural and custom related boundaries. People evaluating their lives being in the middle of it, they face up with the fact that they will not fulfill all their goals, younger couple are looking for their way through life considering some possibilities. The older couple achieves some goals, they try to cope with those not accomplished by accepting what the life offers them. 